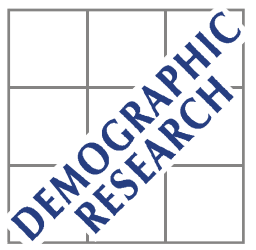

Demographic Research a free, expedited, online journal of peer-reviewed research and commentary in the population sciences published by the Max Planck Institute for Demographic Research Konrad-Zuse Str. 1, D-18057 Rostock · GERMANY www.demographic-research.org

DEMOGRAPHIC RESEARCH

VOLUME 14, ARTICLE 21, PAGES 509-540

PUBLISHED 28 JUNE 2006

http://www.demographic-research.org/Volumes/Vol14/21/

DOI: $10.4054 /$ DemRes.2006.14.21

Research Article

Internal migration and household living conditions in Ethiopia

Blessing Uchenna Mberu

(C) 2006 Max-Planck-Gesellschaft. 


\section{Table of Contents}

1 Introduction $\quad 510$

2 The historical and political context of migration in Ethiopia 510

3 Internal migration and household living conditions 513

$4 \quad$ Data, measures and methods $\quad 515$

$\begin{array}{lll}4.1 & \text { Data } & 515\end{array}$

4.2 Measures $\quad 516$

4.2.1 Dependent variable $\quad 516$

4.2.2 Independent and control variables $\quad 519$

$\begin{array}{lll}4.3 & \text { Analytical methods } & 521\end{array}$

5 Results 522

$5.1 \quad$ Socioeconomic characteristics of the study population 522

5.2 Migration and living conditions: bivariate analysis result 525

$\begin{array}{lll}5.3 & \text { Multivariate analysis } & 527\end{array}$

$\begin{array}{lll}6 & \text { Discussion and conclusions } & 530\end{array}$

$7 \quad$ Acknowledgements $\quad 534$

References $\quad 535$ 


\title{
Internal migration and household living conditions in Ethiopia
}

\author{
Blessing Uchenna Mberu ${ }^{1}$
}

\begin{abstract}
Using the 1998 Migration, Gender and Health Survey in Five Regions of Ethiopia, and multivariate regression techniques, this paper examines the relationship between internal migration and household living conditions. The analysis finds significant living condition advantage of permanent and temporary migrants over non-migrants, primarily linked to migration selectivity by education and non-agricultural income. Once the independent effects of these variables are controlled, no statistical significant independent association exists between migration status and living conditions. Government policies of resettlement in the 1980s and ethnic federalism of the 1990s may have engendered stress migration and exacerbated poor living outcomes for return migrants. The resort to migration and/or resettlement as an individual or government policy response to periodic unfavorable conditions in places of origin is not strongly supported by this analysis as the key to improved living conditions. Promoting higher education and opportunities for employment outside the agricultural sector are more likely to yield improved living conditions in Ethiopia.
\end{abstract}

\footnotetext{
Blessing U. Mberu is a Senior Lecturer at Abia State University, Uturu, Nigeria, currently a doctoral student in the Department of Sociology, Brown University, Providence, Rhode Island, U.S.A. He was a Research Intern at the African Population and Health Research Center, Nairobi, Kenya, when this study was completed. Email: Blessing_Mberu@brown.edu.
} 


\section{Introduction}

Increases in internal migration associated with economic and political transitions in countries of Asia, Africa, Latin America and the Pacific (Gurmu et al, 2000) have made migration a salient feature of life in developing countries. Ethiopia is one of the countries in Africa with a relatively high level of internal migration and population redistribution. This is associated with the country's economic transition from a socialist to a market-oriented economy, critical political changes since the 1970s through 1990s, and civil war and famine (Kiros and White, 2004; Berhanu and White, 2000; Kibreab, 1996; Kloos, 1992; Clapham, 1991; Kidane, 1989). Researchers have shown how the character, direction, and volume of migration in Ethiopia in the last two to three decades have been shaped by political instability, decline in the agricultural sector, and government resettlement policies of the 1980s, whose official objective was to prevent famine and attain food security (Gebre, 2001; Ezra, 2001). Under these circumstances, migration became not only an individual or family response to an adverse socioeconomic, physical and political environment, but also an official government policy.

While these forces have combined to promote the redistribution of the population over the last several years (Berhanu and White, 2000), empirical assessments of the consequences of these movements on the living conditions of migrants and their households in Ethiopia remains limited. Recent studies have established links between migration and food insecurity (Gebre, 2001), and between the migration status of parents and child immunization (Kiros and White, 2004). However the links between migration and household welfare have not been made. This paper uses survey data from five regions of the country to construct a household living conditions index, and employs multivariate models to examine the association between migration and household living conditions, controlling for individual and socioeconomic characteristics.

Understanding the consequences of migration on living conditions at the household level can aid our understanding of the broader problem of poverty in subSaharan Africa. In the context of Ethiopia, it will help to identify the groups most vulnerable to poor living conditions and factors relevant to promoting household welfare in an environment of recurrent political instability, war, famine and economic decline over the last three decades (Lindstrom and Berhanu, 1999). 


\section{The historical and political context of migration in Ethiopia}

Ethiopia with a 2005 estimated population of 73 million is the second most populous country in Africa. Unique among African countries, the ancient Ethiopian monarchy maintained its freedom from colonial rule, with the exception of the 1936-41 Italian occupation preceding and during World War II. In 1974 a military junta, the Derg, deposed Emperor Haile Selassie (who had ruled since 1930) and established a socialist state. Following the socialist revolution, two major wars violently ravaged the country:

1) The Ethiopia-Somali dispute over the Ogaden region, which led in 1977-78 to the largest conventional war between independent African states; and 2) the war between central Ethiopian government and movements seeking separate independence for Eritrea. In the wake of these wars, lesser but still devastating conflicts proliferated in the region: the civil war in northern Somalia, the Afar and Oromo movements, and the Tigray resistance in Northern Ethiopia (Clapham, 1991).

The Derg regime was characterized by acts of repression against opposition forces and their sympathizers inside Ethiopia. The political repression reached its zenith in 1977 with the declaration of the Red Terror: support for the revolutionary motherland or death was the choice offered to Ethiopians by their new military leaders. The repression was concentrated in urban areas of Ethiopia, especially Addis Ababa, which was the center of opposition. In Eritrea, the assumption of state power by the Derg was met by intensified resistance prompting the Derg to unleash its terror in both rural and urban areas in order to break the resistance. Urban and even remote rural areas became scenes of military confrontations (Kibreab, 1996), with considerable loss of life and property and massive internal displacements to Ethiopian cities, particularly Addis Ababa, as well as migration across international borders (Kibreab, 1987). Consequently, Ethiopia was one of Africa's largest producers of refugees up until the early 1990s (Bariagaber, 1995).

Ethiopia suffered one national famine in 1973-74 during which an estimated 250, 000 people died (Kidane, 1989). During the post revolutionary period, the country witnessed three major droughts (1977-78, 1987-1988, and 1993-1994) and a catastrophic national famine in 1984-1985 (Webb and von Braun, 1994). The 1984-85 famine was the most catastrophic Ethiopia experienced in the $20^{\text {th }}$ century and reportedly more than a million people died (Kidane, 1989; Webb and von Braun, 1994). As part of its response to the famine, the Derg regime launched a massive national resettlement and villagization program intended to bring dispersed rural farmers from drought-prone areas in the north into concentrated farming cooperatives, mostly in western Ethiopia. Kloos (1990) estimated that the 1984-85 resettlement program resulted in the movement of about 600,000 drought victims from northern and central Ethiopia to the western part of the country. This controversial resettlement program, 
ostensibly a long-term famine prevention measure, exacerbated the food crisis by not only interfering with agricultural production but also disrupting social relations (Cohen and Isaksson, 1987). Consequently, the program engendered discontent among the peasants and out-migration flows towards cities to avoid living in settlements established and controlled by government (Berhanu and White, 2000).

Torn by bloody coups, uprisings, wide-scale drought, and massive refugee problems, the socialist military regime was finally toppled in 1991 by a coalition of rebel forces, the Ethiopian People's Revolutionary Democratic Front (EPRDF). Since coming to power, the EPRDF has promoted a policy of ethnic federalism as a form of democratization of Ethiopian society. The country is ethnically heterogeneous (Oromo $40 \%$, Amhara and Tigre 32\%, Sidamo 9\%, Shankella 6\%, Somali 6\%, Afar 4\%, Gurage $2 \%$, other $1 \%$ ), and the new leaders established largely ethnic-based territorial units. The politics of ethnicity have thus become the defining feature of governance, access to power and resources, development, and management of public affairs. One notable effect of this policy has been the massive population redistribution, particularly the return migration of settlers from Western Ethiopia back to their region of ethnic origin in the North.

Despite the low level of economic development, population movement in Ethiopia is substantial. Rural-rural and rural-urban migration was a result of the accumulated impact of famines and Ethiopians' survival strategies (Mariam, 1985; CSA, 1992; Kloos and Lindtjorn, 1994; Kiros and White, 2004). In addition, the country has been undergoing a major transformation from a centrally planned to a market-oriented economy since the current government came to power in 1991. Under such transformations, internal migration tends to play an increasing role both demographically and economically (Kiros and White, 2004).

One important dimension of internal population movement in Ethiopia is its link to urbanization. Ethiopia is largely under-urbanized, according to African standards. Recent estimates indicate that in 1975 only 9.5 percent of the population lived in urban areas. For Africa overall, the percentage was 25.1 (Golini et al, 2001). The importance and attraction of urban centers as destinations for migrants was heightened during the post revolutionary period following the opening of branch offices of mass organizations, government and non-governmental agencies that created opportunities at district, provincial and regional levels of the country. Urban growth was especially evident in the northern half of Ethiopia, where most of the major towns are located. As a result of intense and rapid growth of new urban centers between 1967-1994, the proportion of the country's urban population resident in Addis Ababa largely declined. At the middle of the last century, the capital was home to slightly less than half of the urban population, while by 2000 it was home to about 24 percent (Golini et al, 2001). Indeed between 1975 and 1984, the pace of growth of cities and towns was reduced. It 
increased rapidly again between 1984 and 1994, but at rates lower than those in the first period. For most towns, an explanation for the decline in growth rates could be the 1975 Rural Land Act. Some researchers argue that the post revolution land reforms and the new socioeconomic structures emerging from the societal reorganization appear to have inhibited rural-urban migration (Rafiq and Hailemariam, 1987). Another factor could be the socioeconomic deterioration of the urban environment, particularly the shortage of housing and lack of jobs, which reduced rural-urban and urban-urban movements. Also differential allocation of investments for development of socioeconomic activities among urban areas could have contributed to maintaining high growth rates of some towns in comparison to others. Some of the country's regional migrational differentials are also linked to environmental factors.

In terms of migrant composition, age-specific sex ratios from the 1994 Ethiopian census show that males dominate females in age groups 30-44 and 45-59, while females dominate males at young and old ages of 0-14, 15-29 and 60-65 years. The female dominance at young ages, particularly at age group 15-29 is linked to marriage-related migration including divorce. The prevalence of the divorced among migrant females is linked to the fact that a divorced woman is socially unaccepted and often under pressure to leave her place of usual residence and migrate to nearby urban centers. Literacy status and educational attainment are significantly linked to rural-urban mobility in the country, with more than half (51 percent) of migrants literate. Indicators from the 1999 Labor Force Survey (LFS) also show that migration flows for 1994-1999 was composed by a significant number of unemployed people (Cassacchia, et al, 2001).

Building on the forgoing historical context, this paper proceeds in subsequent sections to address the extent to which the migration patterns detailedly reviewed, relates to the living conditions of Ethiopian households.

\section{Internal migration and household living conditions}

In sub-Saharan Africa, there is a consensus that improvement in economic circumstances is the primary motivation for internal migration (Adepoju, 1977). African migration is fundamentally a family affair, rather than an individual activity, and the sending of remittances by migrants is identified as one of the strongest and most pervasive phenomena in Africa's migration systems (Adepoju, 1995). Accordingly, individual migration enables the household to maximize its chances for survival by diversifying its sources of income and spreading its risks (Stark and Bloom, 1985). Arhinful (2001) shows how important assistance from Ghanaian migrants is to their households. These remittances, which come in the form of transfers of money and goods (clothes, electrical equipment, medicines, and vehicles), provide material support 
in times of sickness and old age, and for education and funerals. In sum, the literature of the 1980s viewed migration in Africa as part of the livelihood and survival strategy for the rural family (Andersson, 2001). Accordingly, population redistribution and the growth of cities and towns are expected to serve as important catalysts for national development and raise the living standards of individual migrants and their households (Gurmu et al, 2000).

In contrast, other studies in the region link migration with negative outcomes. Of particular concern is the selectivity of migration for the young, the educated, the innovative, and the energetic into rural-urban migration, leaving behind in rural areas the very young, the apathetic, the retired and tired, the illiterate and the infirmed. Thus those who will stimulate the local economy and contribute to improvement in household living conditions are lost, perpetuating rural poverty and dependency, as well as undermining rural social viability (Lockwood, 1990; Makinwa, 1981; Adepoju, 1983; Dijk et al, 2001).

Researchers are also increasingly pointing to the vulnerability of migrants to adverse living conditions in their urban destinations. The rapid urbanization in the region, the unprecedented growth in the size of the population of young people, and the declining economic performance of most African countries have been linked to a new face of poverty, with a significant proportion of the population living below the poverty line in over-crowded slums and sprawling shanty towns around major cities (NISER, 1997; UN-HABITAT, 2003). This pattern of urban living is characterized by high levels of unemployment and underemployment, poverty, crime, risky reproductive behavior, generally debilitating environmental conditions, and poor health outcomes (Lloyd, 2005; APHRC, 2002; Brockerhoff and Brenan, 1998).

In these assessments, there is a failure to emphasize the socio-economic, political and environmental contexts in which most migration in sub-Saharan Africa take place. Apart from civil wars, many countries in the region are plagued with recurring droughts, famine, political conflicts and transitions, as well as unfavorable government policies that often trigger movement of the most vulnerable poor. The disruptions associated with these forces complicate the model of migration both as a major component of population change and as a determinant or consequence of economic development (Adepoju, 1977). Yet what happens in such contexts, which are typical of several African countries, is relevant in understanding the relationships between migration and human well-being in the region.

The history of Ethiopia in the last three decades as reviewed above made outmigration for many not just the rational choice but the only choice. Dejene (1990) suggests that migration from the villages of Wollo in northeast Ethiopia to the resettlement villages was a last resort and for migrants the choice was often between death and migration. Consequently, those who move are often the economically 
marginally-embedded in the place of origin with no locational incentive to stay. Gurmu et al (2000) identifies particularly the increased volume of movement of vulnerable women and young people with little education and few job skills, with a high proportion being domestic or service workers. In the same light, Ezra (2001) demonstrates that rural out-migration in northern Ethiopia has been a response to push factors related to ecological degradation and poverty in rural areas, rather than a response to pull factors from urban areas. Under these circumstances, the potential outcomes of such moves are hardly optimistic.

It is against this backdrop that this paper provides a unique opportunity to examine a recent survey from Ethiopia for evidence of whether the massive internal population movements during the last three decades translated to improved economic circumstances of migrant households. The study focuses on household living conditions on the premise that poverty is about people and its detrimental outcomes play out in the living conditions of men, women and children in the household (Gage et al, 1997).The central hypothesis of the study is that if the "benefits-of-migration" model is true for Ethiopia, then the migration status of the head of a household will affect the living conditions of the household. Household heads are chosen as the reference persons based on the assumption that the economic circumstance of the head of a household is the single most important indicator in determining a family's economic status (McLanahan and Booth, 1989).

\section{Data, measures and methods}

\subsection{Data}

This analysis utilizes data from the 1998 Migration, Gender and Health survey conducted in five regions of Ethiopia by the Demographic Training and Research Center, Institute of Development Research, Addis Ababa University and the Population Studies and Training Center, Brown University, Providence, Rhode Island, United States of America. The collection of data followed a multi-phase sampling design described in detail in the primary research report (Gurmu et al, 2000). The initial selection of regions included the four most populous - Oromia, Amhara, SNNPR (Southern Nations, Nationalities, and Peoples Region) and Tigray, - plus the national capital, Addis Ababa. Within the selected regions, sampling involved several stages with units of observation (individuals and households) randomly drawn into the sample. A total of five urban and four rural locations were sampled. The urban locations were the country's capital and primate city (Addis Ababa), three regional capital cities (Makele, Bahr Dar, Awassa) and one zonal town (Jimma) in Oromia. In these urban 
places, weredas (districts) were selected that were known from the census data to have high concentrations of migrants. Kebeles (neighborhoods) were then chosen, again on the basis of high concentration of migrants gleaned from Kebele authorities and key informants. Households within kebeles were then listed, using lists of households prepared by the Kebele administration and specific households were randomly selected for inclusion in the survey. For the rural sample, in each of the four regions outside Addis Ababa, one wereda (rural district) was selected, and within it two or three Peasant Associations - PAs (large villages) were selected for sampling. These PAs were chosen to represent areas of either high out-migration or high in-migration, or possibly a mix of both. Attempts were made to choose both a highland and a lowland community. For the villages within these PAs, household lists were obtained and households were randomly sampled for inclusion in the survey. For both urban and rural households, an approximate balance was maintained between male and female respondents to allow for gender comparison. Data on migrant status, living conditions in the household and the demographic characteristics of respondents were collected using the household questionnaire. For the purposes of this analysis, 1608 heads of households covered by the survey were selected as reference persons. Following data exploration, 1554 heads of household who have complete information on all the highly correlated variables relevant for the construction of a household living conditions index were selected for this study. Fifty-four households whose living conditions could not be determined due to missing information on some of the relevant household items were dropped from the analysis. Except for the missing information, there is no significant difference between the characteristics of those households that were dropped and those included in the analysis.

\subsection{Measures}

\subsubsection{Dependent variable}

The outcome variable in this analysis is household living conditions. The survey data set did not have income measures or consumption expenditures, which are conventionally used as indicators of household economic status. Also, the traditional concept of poverty, which places emphasis on income, has been identified in developing countries as too narrow (NISER, 2003), and often there are issues with the validity of income data due to reporting errors. Montgomery et al (2000) have noted that in developing countries, households often draw their incomes from multiple sources that can change from year to year and even from season to season. The transitory nature of some employment, coupled with the uncertainty of net economic 
return, makes it implausible to regard any one year's income as representative of the incomes earned over the longer time span in which demographic decisions are made (ibid). In consideration of these, sets of questions in the survey that relate to housing and living conditions were used to construct household living condition index. First, households were asked about the physical quality of their houses, in terms of materials used for building the wall, the roof and the floor, as well as the main source of light for the household, the nature of bathing and toilet facilities, and the number of rooms in the house. Second, they were asked to report about the ownership of various means of personal transportation and other household durables - a car, a bicycle, television, sofa, radio, electric fan, electric iron, electric stove, electric mitad, clock, insecticide sprayer, cassette recorder, cylinder, telephone, refrigerator, cart and plough. In order to use these variables to rank household living conditions, they were aggregated into a living standards index using principal component analysis. This data reduction method is used to determine the number of factors that can adequately explain observed correlations among variables. It has the advantage of compressing an assortment of variables into a few key factors, taking into account the correlations between them, and assigning appropriate weights to each of the observed variables in the form of factor scores. This procedure creates a set of mutually uncorrelated components of the data, and the first principal component is intuitively the linear index of the underlying variables that captures the most common variation among them (Filmer and Pritchett, 1999). In this analysis, of the 26 household items selected for an exploratory factor analysis, 19 that are highly correlated were selected as proxy variables for constructing the living standard index. The increase of the variance explained from 30 percent in the exploratory analysis to 36 percent for the 19 items, confirms that the higher the correlation between items in the analysis, the higher the variance explained (Kim and Mueller, 1978). The dependent variable (the index of living conditions) therefore is the regression scores of the first principal component (ranging from -1.47 to 2.97 with zero mean and standard deviation of 1). The wealth index score is a relative measure of household living conditions. The higher negative scores indicate poor living conditions; higher positive scores indicate higher and better standards of living. The nineteen variables used in the index and their factor loadings in two components are presented in Table 1. 
Table 1: Component matrix of living index variables in Ethiopia

\begin{tabular}{lll}
\hline \multirow{2}{*}{ Household Items } & \multicolumn{2}{c}{ Components } \\
\cline { 2 - 3 } & $\mathbf{1}$ & $\mathbf{2}$ \\
\hline Floor material & .723 & .029 \\
Roof material & .329 & .678 \\
Rooms for household & .608 & .116 \\
Source of water supply & .560 & .236 \\
Toilet facility & .685 & .074 \\
Bathroom facility & .628 & -.363 \\
Wall material & .495 & .413 \\
Window in house & .483 & .096 \\
Kitchen facility & .600 & .576 \\
Source of light & .507 & -.117 \\
Source of cooking fuel & .535 & .323 \\
Radio & .727 & -.276 \\
Television & .660 & .339 \\
Cassette Recorder & .686 & -.205 \\
Electric mitad & .550 & -.294 \\
Refrigerator & .637 & -.258 \\
Telephone & .616 & -.261 \\
Clock & .706 & -.269 \\
Sofa set & .525 & -.351 \\
Eigen-values & & 1.95 \\
\% of variance explained & 6.88 & $10 \%$ \\
& $36 \%$ & \\
\hline
\end{tabular}

Extraction Methods: Principal Component Analysis.

While it has been argued that an asset index may not be a proxy for current standards of living, or appropriate for all kinds of poverty analysis following the multidimensional concepts of poverty, inequality, and inequity (Gwatkin et al., 2000), Filmer and Pritchett $(1998 ; 1999)$ show that the index has performed as well as more traditional measures such as household-size adjusted consumption expenditure, and point to its usefulness in establishing differences in long-run household wealth. Other recent research that has used this approach confirms that the asset-consumption relationship is quite close (Montgomery et al., 2000; Wagstaff et al., 1991). In a study of the socio-economic differences in health, nutrition, and population in Kenya (one of Ethiopia's neighbors), Gwatkin et al (2000) building on this perspective, conclude that asset ownership can be taken as a reasonable satisfactory proxy for consumption, in addition to being an indicator of economic status in its own right. In the Ethiopian 
context therefore (with its obvious limitations to collecting data on income and consumption), the use of household asset index represents a pragmatic approach to get around the problem of data limitations to examine issues (such as household welfare) critical for understanding poverty and providing evidence for poverty alleviation policies.

\subsubsection{Independent and control variables}

The survey provided data on migration status of heads of households in four migrant categories - non-migrants, permanent migrants, temporary migrants and return migrants. Migration is defined as movement out of a rural or urban place of origin that lasted for at least six months. Permanent migrants are those who left their places of origin and continue to reside in their places of destination. Return migrants are those who have lived outside their places of origin for up to six months but are currently returned to place of origin. Temporary migrants are migrants residing outside their places of origin for at least six months but periodically move back and forth between origin and destination. These four migration categories adequately represent the history of Ethiopia's migration streams (Dejene, 1990; Gebre, 2001).

The study controls for socioeconomic and demographic factors, which includes education, gender, age, income sources (a close proxy for occupation), marital status, household size, housing tenancy, age of household, rural or urban and region of residence.

Education is the main source of human capital formation and ultimately a crucial tool for poverty avoidance. It is expected that living conditions of households will vary across different levels of educational attainment, with higher education more likely to predict better living standards. Education is coded into four categories: no education (reference), primary, secondary and higher education. The role of age in determining living conditions conventionally reflects a curvilinear inverted U-shaped graph, indicating poor living conditions at the younger and older age cohorts and better living conditions at the middle high productive years. The age variable is in three cohorts: 1529 (reference category), 25-49 and 50 and older. As a result of the cultural barriers that limit women's access to productive resources relative to men, it is expected that household living conditions will vary by gender of the head. The gender variable is a dummy coded 0 if the head of household is a male and 1 if a female. The religion of head of household is presented in three categories: Orthodox (reference), Muslims, and Protestant/Catholic/Other. Marital Status is in three categories: never married (reference), currently married and previously married (divorced, separated and the widowed). Household size is in three categories: small-sized households of 1-5 persons 
(reference), medium-sized households of 6-10 persons and large households of 11 members and above. In terms of income sources, the distinction is made between those who earn their income from agriculture coded 0 and others who do not coded 1 . Nonagricultural sources of income include non-agricultural businesses, wages, salaries, welfare/pension, remittances and rents.

Home ownership contributes to the well-being and happiness of families, and intensifies upward social mobility and wealth accumulation (Megbolugbe and Linneman, 1993; Wachter and Megbolugbe, 1992; Tipple and Willis, 1991). In subSaharan Africa, however, housing tenancy is more complicated than in developed countries. Researchers in the region have established that tenure choice transcends the two modal prototypes of owners and renters. In addition to this bimodal prototype are rent-free consumers or family-housers with family rights to housing either through inheritance or the favor of a living owner (Tipple and Willis, 1991). Indeed, Korboe (1992) estimates that about 25 per cent of all households are likely to fall within this category. While it may be argued that home ownership is implicated in the outcome of this study, substantial research have demonstrated that housing is fundamentally more of a producer than a consumer durable and has suggested that home ownership is a determinant not an indicator of living standards (Montgomery and Hewett, 2005). This variable is coded into three categories: owner-occupier housing (reference), rented homes and rent-free housers.

The survey determined households established before 1984 and those establish after. The year 1984 marked the 10th year anniversary of the coming to power of the socialist government (the Derg). Households formed before or during the early years of the regime, prior to the 1984-85 famine, are expected to benefit from the stability of previous years and the significant redistribution of property particularly land holdings. Those formed after 1984-85 are expected to be adversely affected by the resistance movements and war during the later years of the revolution.

There is a growing sentiment in sub-Saharan Africa, that economic stagnation in recent times has made some urban areas, including large city slums, worse off than rural areas in terms of unemployment, cost of living, poverty, and access to health and schooling (UN-HABITAT, 2003). However, a higher proportion of the continent's population still resides in rural areas and is exposed to the vagaries of the economic deterioration that the region has experienced in the last three decades. This is compounded for rural areas by the lack of access to social and health facilities caused by the historical development biases that created "islands of privilege" in urban areas (Harrison, 1982; Lipton, 1976). Consequently, economic deprivation and its attendant living disadvantages in terms of health and other livelihood outcomes remain potentially profound in rural Africa (Zulu, Dodoo, \& Ezeh, 2002). The situation in Ethiopia is expected to be exacerbated by the fact that rural Ethiopia is the worst hit by 
environmental degradation and famine. This expectation is controlled for with a dummy variables coded 0 if residence is urban and 1 if rural.

Considerable differences exist among Ethiopian regions with respect to economic potentials, population densities, socioeconomic development and urbanization. The potential of Addis Ababa as an important destination for migrants is linked to its role as the national capital, which signifies a better concentration of facilities and opportunities (Gurmu et al, 2000). However the impact of the political conflicts and attendant economic deterioration of the city leaves a less optimistic expectation of the better life for the metropolis. The regional effects are examined along five regions: Oromiya (reference), Tigray, Addis Ababa, Amhara, and SNNPR (Southern Nations, Nationalities, and Peoples Region).

\subsection{Analytical methods}

The analysis of data includes a description of the study population followed by a bivariate analysis of the correlations between all categories of independent variables and living conditions index. Finally, a multivariate model using Ordinary Least Squares (OLS) is estimated to determine the independent effects of the predictor variables on living conditions net the effects of all other variables. The multivariate regression model developed for this purpose is:

$$
\begin{aligned}
\mathrm{Y}=\quad & \beta 0+\sum \beta 1 \mathrm{k} \text { (Migration status) } \mathrm{k}+\sum \beta 2 \mathrm{k}(\text { Education }) \mathrm{k}+\beta 3(\text { Sex of head })+ \\
& \sum \beta 4 \mathrm{k}(\text { Age of Head }) \mathrm{k}+\sum \beta 5 \mathrm{k}(\text { Religion }) \mathrm{k}+\sum \beta 6 \mathrm{k}(\text { Marital Status }) \mathrm{k}+ \\
& \sum \beta 7 \mathrm{k}(\text { Income Source }) \mathrm{k}+\sum \beta 8 \mathrm{k}(\text { Housing Tenancy) } \mathrm{k}+ \\
& \left.\left.\sum \beta 9 \mathrm{k}(\text { Household Size }) \mathrm{k}+\beta 10 \text { (Household Age }\right)+\beta 11 \text { (Rural Residence }\right)+ \\
& \sum \beta 12 \mathrm{k} \text { (Region of Residence) } \mathrm{k}+\varepsilon,
\end{aligned}
$$

where, $\mathrm{k}$ represents categories of the predictors.

In consideration of multicollinearity concerns, with Addis Ababa being wholly urban, a multicollinearity test was conducted for all variables in the regression. The colinearity statistics ${ }^{2}$ (tolerance and VIF (variance inflation factor)) do not indicate a redundant predictor among all categories of independent and control variables. However, to check for the consistency of the estimates and the poverty level of Addis

\footnotetext{
${ }^{2}$ Colinearity test produce the tolerance statistics and Variance Inflation Factor (VIF). The tolerance is an indication of the percentage of variance in a predictor variable that cannot be accounted for by the other predictors, hence very small values indicate that a predictor is redundant. Values that are less than .10 may merit further investigation and the variable may need to be dropped from the analysis. The Variance Inflation Factor (VIF) is $1 /$ tolerance and as a rule of thumb, a variable whose VIF is greater than 10 may merit further investigation and may need to be considered as redundant. The test on all the variables in this analysis turned out no redundant predictor. However, in order to further address the concern of multicollinearity, over and above the test, a separate regression analysis without the urban-rural variable was run. The outcome (not shown) did not significantly alter the relative poverty status of the regions shown in Table 4 .
} 
Ababa relative to other regions, a regression model was run without the rural-urban variable and a fixed effects ${ }^{3}$ model was also run to control for regional unobservable factors that might bias the estimates.

\section{Results}

\subsection{Socioeconomic characteristics of the study population}

Table 2 summarizes the characteristics of the study population and their distribution by migration status. The table shows that most (58 percent) heads of household are permanent migrants. The corresponding proportions for other migration categories are: 5.4 percent temporary migrants, 8.0 percent return migrants and 28 percent nonmigrants. The distribution conforms to high levels of out-migration from places of origin that is generally associated with famine, war and government-promoted resettlement programs.

The distribution of migrants by gender reflects the proportion of male to female heads of household in the overall sample, except for permanent migrants where the proportion of female heads is relatively higher than in the other migrant categories. This may be a reflection of what is observed from the national census that female heads are socially under pressure to migrate in the event of divorce or widowhood.

Table 2: Socioeconomic characteristics of heads of households by migration status

\begin{tabular}{llllll}
\hline & $\begin{array}{l}\text { Total } \\
(\%)\end{array}$ & $\begin{array}{l}\text { Non-Migrants } \\
(\%)\end{array}$ & $\begin{array}{l}\text { Permanent } \\
\text { Migrants (\%) }\end{array}$ & $\begin{array}{l}\text { Return Migrants } \\
(\%)\end{array}$ & $\begin{array}{l}\text { Temporary } \\
\text { migrants (\%) }\end{array}$ \\
\hline Gender & & & & & \\
Male & 70.5 & 71.5 & 67.7 & 85.5 & 74.4 \\
$\begin{array}{l}\text { Female } \\
\text { Age of Head of }\end{array}$ & 29.5 & 28.5 & 32.3 & 14.5 & 25.6 \\
$\begin{array}{l}\text { Household } \\
15-29\end{array}$ & 14.3 & 16.9 & & & \\
$30-49$ & 46.7 & 40.0 & 8.5 & 20.2 & 59.8 \\
50 and above & 39.1 & 43.1 & 50.1 & 53.2 & 28.0 \\
Marital Status & & & 41.5 & 26.6 & 12.2 \\
Never Married & 8.2 & 9.6 & 4.1 & & \\
Currently Married & 68.6 & 74.5 & 69.9 & 4.0 & 55.7 \\
Previously Married & 21.4 & 15.9 & 25.9 & 76.6 & 34.2 \\
\hline
\end{tabular}

\footnotetext{
${ }^{3}$ To address the concern of regional unobservables that may bias the estimates; a fixed effects regression model was run by including regional dummies. This controls for the average differences in any observable or unobservable differences across the regions. However the result did not yield any significant difference from the results presented in Table 4.
} 
Table 2: (continued)

\begin{tabular}{|c|c|c|c|c|c|}
\hline & $\begin{array}{l}\text { Total } \\
(\%)\end{array}$ & $\begin{array}{l}\text { Non-Migrants } \\
\text { (\%) }\end{array}$ & $\begin{array}{l}\text { Permanent } \\
\text { Migrants (\%) }\end{array}$ & $\begin{array}{l}\text { Return Migrants } \\
(\%)\end{array}$ & $\begin{array}{l}\text { Temporary } \\
\text { migrants (\%) }\end{array}$ \\
\hline \multicolumn{6}{|l|}{ Household Size } \\
\hline Small households & 45.1 & 48.3 & 37.9 & 58.1 & 87.8 \\
\hline $\begin{array}{l}\text { Medium } \\
\text { Households }\end{array}$ & 46.9 & 49.4 & 50.3 & 36.3 & 11.0 \\
\hline Large Households & 8.0 & 2.3 & 11.8 & 5.6 & 1.2 \\
\hline $\begin{array}{l}\text { Educational } \\
\text { Attainment } \\
\text { No education }\end{array}$ & 37.9 & 48.7 & 36.4 & 33.9 & 11.3 \\
\hline Primary education & 24.1 & 22.1 & 25.7 & 26.6 & 11.8 \\
\hline Secondary & 23.0 & 18.2 & 24.1 & 27.4 & 35.0 \\
\hline Higher education & 14.3 & 11.0 & 13.7 & 12.1 & 35.0 \\
\hline \multicolumn{6}{|l|}{ Religion of Head } \\
\hline Orthodox & 67.1 & 56.9 & 76.0 & 50.0 & 56.1 \\
\hline Prot/Cath/Others & 7.2 & 2.3 & 8.3 & 2.4 & 26.8 \\
\hline Muslim & 25.2 & 40.7 & 15.8 & 47.6 & 17.1 \\
\hline \multicolumn{6}{|l|}{$\begin{array}{l}\text { Source of Income } \\
\text { of Head }\end{array}$} \\
\hline Agric. Income & 29.4 & 68.9 & 8.4 & 67.5 & 1.3 \\
\hline Non-Agric. Income & 69.7 & 31.1 & 91.6 & 32.5 & 98.8 \\
\hline \multicolumn{6}{|l|}{ Housing Tenancy } \\
\hline $\begin{array}{l}\text { Status } \\
\text { Owner occupier }\end{array}$ & 63.3 & 86.7 & 53.7 & 83.1 & 18.5 \\
\hline Renters & 34.6 & 12.6 & 45.0 & 16.9 & 63.0 \\
\hline Rent-free housers & 2.0 & 0.7 & 1.3 & 0.00 & 18.5 \\
\hline \multicolumn{6}{|l|}{$\begin{array}{l}\text { Household } \\
\text { Formation }\end{array}$} \\
\hline Before 1984 & 62.6 & 78.5 & 76.9 & 62.1 & 10.6 \\
\hline After 1984 & 23.4 & 21.5 & 23.1 & 37.9 & 89.4 \\
\hline \multicolumn{6}{|l|}{$\begin{array}{l}\text { Place of } \\
\text { Residence }\end{array}$} \\
\hline Rural & 32.7 & 72.0 & 10.3 & 74.2 & 8.5 \\
\hline \multicolumn{6}{|l|}{$\begin{array}{l}\text { Region of } \\
\text { Residence }\end{array}$} \\
\hline Tigray & 19.7 & 29.2 & 18.4 & 8.1 & 1.2 \\
\hline Amhara & 22.4 & 25.3 & 19.0 & 21.8 & 46.3 \\
\hline Oromiya & 17.2 & 17.5 & 16.1 & 29.8 & 9.8 \\
\hline SNNPR & 22.0 & 16.4 & 24.4 & 33.1 & 8.5 \\
\hline Addis Ababa & 18.7 & 11.6 & 22.2 & 7.3 & 34.1 \\
\hline Total & $\mathrm{N}=1554$ & $n=440$ & $n=908$ & $n=124$ & $n=82$ \\
\hline
\end{tabular}

Data Source: Migration, Gender and Health Survey in Five Regions of Ethiopia, 1998. 
The study population is one with very low levels of education: 24 percent have only primary education and 38 percent have no education. While this outcome is higher than the national literacy average, it reiterates the low levels of literacy in the country. When examined against migration status, there seem to be little selection, as those with primary or no education are almost evenly distributed among migrants and non migrants. Among non-migrants, 48 percent have no education and 22 percent attained primary education. For permanent migrants the outcome is 36 percent and 26 percent respectively. For return migrants the distribution is 35 percent (no education) and 26 percent (primary education). It is only among temporary migrants that an unusual 70 percent have at least a secondary education. This outcome may be related to the opportunities offered by government employment for educated Ethiopians who are posted to different regions of the country as teachers, health officers and agricultural extension workers. To the extent that these are government postings that often change at the whims of government policy and/or senior government officials, such middle level professionals are most likely to identify themselves as temporary migrants. There is also a noticeable presence of university students and poorly educated male and female service workers in urban areas among this group. In fact, job assignment is found to play a leading role on all their earlier moves (Gurmu et al, 2000). This may explain not only their levels of educational attainment in this sample but also their engagement outside the traditional farming sector, with consequent living conditions advantage relative to non-migrants discussed subsequently. This interpretation is consistent with results from the 1999 Labor Force Survey in Ethiopia, which identified not only a substantial category of migration due to transfer of the place of work, accounting for 23 percent of total migrant population in 1999, but also its urban destination character (Casacchia et al, 2001).

Orthodox Christianity is the dominant religious affiliation of all respondents constituting 67 percent of the study population. Again this parallels the dominance of Orthodox Christianity in the general population. Examined against migration status, the same picture prevails except that Muslims constitute a significant proportion of nonand return migrants. Those currently married are 68 percent of the total sample and dominate all migration categories, except among temporary migrants where the unmarried are dominant.

Twenty-nine percent of heads of household earn their incomes from agriculture, and 70 percent earn incomes from non-agricultural sources. This outcome is driven by permanent and temporary migrants among whom only 8.4 and 1.3 percent respectively earn agricultural incomes. Among non- and return migrants, the outcome is reversed with 69 and 68 percent respectively earning their incomes from agriculture.

Approximately 45 percent of the population live in small households of 5 persons or less and 46 percent are heads of medium-sized households of six to ten persons. 
Only 8 percent of households are composed of eleven persons or more. The dominance of small and medium-sized families prevails among migrants and non-migrants, and may reflect the decline in fertility that occurred in Ethiopia over the 1980s through the 1990s under the duress of economic and political crises (Lindstrom and Berhanu, 1999).

About 62 percent of households were formed before 1984; this distribution also holds for return migrants, and is even larger for permanent and non-migrants. However temporary migrants have relatively younger households with 89 percent of them formed after 1984. In terms of rural and urban residence, one observes a bi-polar distribution. While over 70 percent of non-migrants and return migrants reside in rural areas, approximately 90 percent of permanent and temporary migrants reside in urban areas. The sample is evenly distributed among the five regions of the country, but there are remarkable regional variations in terms of their migration status. Most non-migrants are concentrated in Tigray and Amhara, while permanent migrants mostly reside in SNNPR and Addis Ababa. Return migrants mostly reside in SNNPR, Oromiya and Amhara (in that order), whereas temporary migrants mostly reside in Amhara and Addis Ababa.

While this paper will underscore the explanations for some of the observed migration patterns, the primary question addressed in subsequent sections is the extent to which these variables and migration status are related to the living conditions of Ethiopian households.

\subsection{Migration and living conditions: bivariate analysis result}

Table 3 shows the correlations between each category of the independent variables and living conditions. In this result, two complementary outcomes are observed.

Table 3: Correlations of categories of independent variables and living conditions index in Ethiopia $(\mathrm{N}=1554)$

\begin{tabular}{lc}
\hline Independent Variables & Correlation Coefficients $(\mathbf{r})$ \\
\hline Migration Status & - \\
Non Migrants & $-.29^{* *}$ \\
Permanent Migrants & $.35^{\star *}$ \\
Return Migrants & $-.15^{\star *}$ \\
Temporary Migrants & -.02 \\
Gender & - \\
Male & .02 \\
Female & .02 \\
& \\
\hline
\end{tabular}


Table 3: (continued)

\begin{tabular}{lc}
\hline Independent Variables & Correlation Coefficients $(\mathbf{r})$ \\
\hline Age of Head of Household & - \\
$15-29$ & $-.08^{* *}$ \\
$30-49$ & $.08^{* *}$ \\
50 and above & -.03 \\
Marital Status & - \\
Never Married & .02 \\
Currently Married & .03 \\
Previously Married & -.04 \\
Household Size & - \\
Small households & $-.18^{* *}$ \\
Medium Households & $.07^{* *}$ \\
Large Households & $.21^{* *}$ \\
Educational Attainment & - \\
No education & $-.34^{* *}$ \\
Primary education & .04 \\
Secondary education & $.22^{* *}$ \\
Higher education & $.27^{* *}$ \\
Religion of Head & - \\
Orthodox & $.11^{* *}$ \\
Protestant and Others & $.07^{* *}$ \\
Muslim & $-.17^{* *}$ \\
Income Source of Head & - \\
Agricultural Income & $-.56^{* *}$ \\
Non-Agricultural Income & $.55^{* *}$ \\
Housing Tenancy Status & - \\
Owner occupier & $-.06^{*}$ \\
Rented home & $.09^{* *}$ \\
Rent-free home & $-.06^{*}$ \\
Household Formation & - \\
Before 1984 & .03 \\
After 1984 & .01 \\
Place of Residence & - \\
Urban & $.59^{* *}$ \\
Rural & $-.59^{* *}$ \\
Region of Residence & - \\
Oromiya & $.11^{* *}$ \\
Tigray & $.11^{* *}$ \\
Amhara & $-.22^{* *}$ \\
SNNPR & $-.07^{* *}$ \\
Addis Ababa & $.09^{* *}$ \\
\hline & \\
\hline &
\end{tabular}

Significance of Correlation (2-tailed test): ${ }^{* * *} \mathrm{P}<.001,{ }^{* \star} \mathrm{P}<.01,{ }^{*} \mathrm{P}<.05$. 
First, being a permanent migrant, an urban resident, earning income from nonagricultural enterprises, living in Oromiya and Tigray regions, and having secondary and higher education are all positively correlated with living conditions. Conversely, living in rural areas of Ethiopia, earning income from agricultural enterprises, having no education, being a non- or a return migrant, living in Amhara region and belonging to a small-sized household of 1-5 persons (in descending order of magnitude) are most negatively correlated with household living conditions. Though these correlations are informative and mostly significant, they are not especially high, the highest being .59 and -.59 (scores for urban and rural residence respectively). The next section presents a multivariate regression analysis which refines and modifies these outcomes by taking account of confounding variables.

\subsection{Multivariate analysis}

In order to determine the net effects of the independent and control variables, four estimated multivariate regression models are summarized in Table 4. In Model 1, with non-migrants as the reference category, the outcome replicates the result of the bivariate analysis above, with permanent migrants better off than other groups in living conditions. Similarly, temporary migrants show significantly better living conditions than non-migrants. However, with the introduction of control variables in Models 2, 3, and 4 , the results generally indicate no independent significant relationship between internal migration status and improved living conditions. In Model 2, controlling for the individual characteristics of the heads of household, the significant advantage of permanent migrants over non-migrants disappeared and temporary migrants become significantly worse off. In Models 3 and 4, controlling for household and community effects, the results indicate no independent significant relationship between the migration status and household living conditions. While these outcomes generally run contrary to the conventional expectations of the benefits of migration as a household survival strategy in a locally restrictive environment, it underscores both the role of migration selectivity in the perceived implication of migration for improved living conditions and the particular historical context of Ethiopia during the last three decades.

Education shows a consistent positive relationship with living conditions. Higher educational attainment of the head of a household is associated with significant increases in household living conditions. In Model 2, having primary education significantly improves living conditions by 24 percent when compared to those with no education. Secondary and higher education improve household living conditions by 72 and 96 percents respectively. In Model 3, with additional controls, the association between education and living conditions remains virtually the same for the same levels 
of education as in Model 2. In Model 4 controlling for urban and rural residence and regional differences, the results show that secondary education improves living conditions by 58 percent and higher education improves living conditions by 86 percent relative to those with no education.

In terms of the gender of head, households with female heads have significantly better living conditions than males. However the strength of the relationship decreases with the introduction of additional controls in Models 3 and becomes only marginally significant in Model 4.

Table 4: $\quad$ OLS regression coefficients of living conditions in Ethiopia $(\mathrm{N}=1554)$

\begin{tabular}{|c|c|c|c|c|}
\hline Variables & Model 1 & Model 2 & Model 3 & Model 4 \\
\hline \multicolumn{5}{|l|}{ Migration Status } \\
\hline Non Migrants & - & - & & \\
\hline Permanent Migrants & $.75^{\star \star *}$ & .07 & & \\
\hline Return Migrants & -.06 & -.10 & & \\
\hline Temporary Migrants & $.39^{* \star *}$ & $-.36^{* *}$ & & \\
\hline \multicolumn{5}{|l|}{ Educational Attainment } \\
\hline No education & & - & - & - \\
\hline Primary education & & $.24^{\star \star \star}$ & $.22^{* * *}$ & $.14^{* * *}$ \\
\hline Secondary education & & $.72^{\star \star \star}$ & $.69^{\star \star *}$ & $.57^{\star \star \star}$ \\
\hline Higher education & & $.96^{* * *}$ & $.96^{* * *}$ & $.86^{* * *}$ \\
\hline \multicolumn{5}{|l|}{ Gender } \\
\hline Male & & - & - & - \\
\hline Female & & $.21^{\star \star \star}$ & $.18^{* *}$ & $.14^{*}$ \\
\hline \multicolumn{5}{|l|}{ Age of Head of Household } \\
\hline $15-29$ & & - & - & - \\
\hline 25- 49 & & $.29^{\star \star \star}$ & $.22^{\star * *}$ & $.19^{* *}$ \\
\hline 50 and above & & $.49^{* * *}$ & $.35^{\star *}$ & $.29^{* * *}$ \\
\hline \multicolumn{5}{|l|}{ Religion of Head } \\
\hline Orthodox & & - & - & - \\
\hline Protestant/Catholic/ Others & & .06 & -.02 & -.01 \\
\hline Muslim & & $.12^{*}$ & .07 & $.17^{\star *}$ \\
\hline \multicolumn{5}{|l|}{ Marital Status } \\
\hline Never Married & & - & - & - \\
\hline Currently Married & & 0.9 & -.02 & -.12 \\
\hline Previously Married & & -.10 & -.14 & $-.21^{*}$ \\
\hline
\end{tabular}


Table 4: (continued)

\begin{tabular}{|c|c|c|c|c|}
\hline Variables & Model 1 & Model 2 & Model 3 & Model 4 \\
\hline \multicolumn{5}{|l|}{ Income Source of Head } \\
\hline Agricultural Income & & - & - & - \\
\hline Non-Agricultural Income & & $1.01^{* * *}$ & $1.12^{* * *}$ & $.36^{\star \star *}$ \\
\hline \multicolumn{5}{|l|}{ Housing Tenancy Status } \\
\hline Owner occupier & & & - & - \\
\hline Rented home & & & $-.40^{\star \star *}$ & $-.35^{\star \star *}$ \\
\hline Rent-free home & & & $-.77^{\star \star *}$ & $-.63^{\star \star *}$ \\
\hline \multicolumn{5}{|l|}{ Household Size } \\
\hline Small households & & & - & - \\
\hline Medium Households & & & $.10^{*}$ & .06 \\
\hline Large Households & & & $.42^{* \star *}$ & $.35^{\star * *}$ \\
\hline \multicolumn{5}{|l|}{ Age of Household } \\
\hline Before 1984 & & & - & - \\
\hline After 1984 & & & .03 & -.001 \\
\hline \multicolumn{5}{|l|}{ Place of Residence } \\
\hline Urban & & & & - \\
\hline Rural & & & & $-1.00^{* * *}$ \\
\hline \multicolumn{5}{|l|}{ Region of Residence } \\
\hline Oromiya & & & & - \\
\hline Tigray & & & & -.01 \\
\hline Amhara & & & & $-.63^{* * *}$ \\
\hline SNNPR & & & & $-.38^{* * *}$ \\
\hline Addis Ababa & & & & $-.44^{* * *}$ \\
\hline Intercept & $-.45 * * *$ & $-1.54^{\star \star *}$ & $-1.37^{\star \star *}$ & 0.13 \\
\hline $\mathbf{R}^{2}$ & .13 & .42 & .47 & .56 \\
\hline F for $R$ Square Change & $77.3 * * *$ & $12.9^{\star \star \star}$ & $27.1^{\star \star \star}$ & $145^{\star \star \star}$ \\
\hline
\end{tabular}

Levels of Statistical Significance: ${ }^{\star * *} \mathrm{P}<.001,{ }^{* *} \mathrm{P}<.01,{ }^{*} \mathrm{P}<.05$

Muslims have marginally better living conditions than other religious groups in Models 2 and 4, though the relationship is not statistically significant in Model 3.

The age of the head of a household has a positive linear relationship with living conditions. As age increases, living conditions increase as well. The eldest age category (those aged 50 years and above) consistently have better living conditions than those in the younger cohorts. In Model 4 with all controls this advantage remains significant. This may be related to the traditional structures that favor the elderly, as well as, their 
accumulated advantages over the life course in a harsh environment and deteriorating economy.

Ethiopians who earn incomes from non-agricultural enterprises like trading, those who earn salaries, and those who receive remittances and rents are significantly better off than those who earn agricultural incomes. This remains true in Models 2 and 3. In Model 4, with regional and urban/rural controls, the variation among different income sources is weaker but remains significant.

In Models 3 and 4, living in a rented home is related to a decrease in household living conditions by 40 percent and 35 percent respectively relative to living in own homes. On the other hand, living in a rent-free home is related to a 77 percent decrease in living conditions in Model 3 and a 63 percent decrease in Model 4.

Looking at the association between household structure and living conditions, the outcome indicates a marginal advantage for medium-sized households (6-10 persons) compared to small-sized households (1-5 persons). However, there is a profound advantage of large household structures (11 persons and above) over small-sized households by 43 percent in Model 3, and 35 percent in Model 4.

Finally, living in rural Ethiopia is associated with a significant decrease in living conditions when compared to living in urban areas. In terms of region of residence, there is no significant difference between living in Oromiya and Tigray. However, relative to living in Oromiya, living in SNNPR, Addis Ababa and Amhara significantly decreases living conditions by 38 percent, 44 percent and 63 percent respectively. The results of the regression model without the urban/rural variable, and that of the fixedeffect model, did not yield significantly different outcomes; hence they were not presented here.

\section{Discussion and conclusions}

The descriptive result indicates high levels of internal migration, confirmed by other studies in the country as both an adaptation mechanism and a survival strategy. In terms of significant levels of return migration identified despite the push factors associated with environmental degradation, famine, and war, researchers cite the resilience of the peasantry to return and bounce back to their normal activities after chaos and destruction (Dejene, 1990; Gebre, 2001). Others point to the political restructuring of the country into new regional federal states according to ethnic and linguistic composition. This new policy aimed at achieving ethnic equality, resulted in massive return migration from resettled communities in the southern parts of the country to the north and the urban centers, particularly during 1991-93 (Ezra, 2001). 
The multivariate results show that the significant living conditions advantage of permanent and temporary migrants over non-migrants in Model 1 are primarily due to selectivity into migration status by education and occupation. A step by step introduction of each variable into the regression pinpoints education and access to nonagricultural sources of income as the individual variables mostly responsible for varying effects of migration status across models (tables not shown). When education was introduced into the analysis, the significant advantage observed for permanent migrants over non-migrants remained but that observed for temporary migrants disappeared. Further, when sources of income (a proxy for occupation) were introduced into the model, the significant advantage of permanent migrants over non-migrants disappeared and temporary migrants became significantly disadvantaged. These outcomes point to the selectivity of permanent migrants into mostly non-agricultural employment and temporary migrants into both higher education and non-agricultural employment. Despite the low levels of education of most permanent migrants (26 percent have primary education and 36 percent had none at all), stable urban residence with an overwhelming access to employment in the non-agricultural sector is key to their living conditions. For temporary migrants, their educational attainment advantage (35 percent have secondary education and another 35 percent attained higher education) and employment mostly in the non-agricultural sector account for their living conditions.

In all models, return migrants indicate a negative association with living conditions relative to non-migrants, though none of the outcomes is statistically significant. Following the government voluntary and involuntary resettlement initiatives of the 1980s and attendant conflicts and clashes (Gebre, 2001), those who moved were likely the marginally embedded in the social and economic structures of origin communities, lacking location-specific incentives to stay (Fischer et al, 1997). Furthermore, the creation of new federated regions based on ethnic nationalities in the early 1990s resulted in massive return migration to places of origin, thus exposing returnees to the same push factors that most likely prompted their initial outward migration. To the extent that government policies generated out-migration to settlements in the south and south western Ethiopia in the 1980s and return migrants to northern origins following policy change in the 1990s, it may be valid to suggest from the result of this study that Ethiopian governments succeeded not only in engendering stress migration but also reinforcing poor living outcomes. Conclusion from ethnographic study of famine and food security in the country seems to support this perspective. The Metekel settlers experienced two widespread famines between 1984 and 1986. The earlier famine began to subside at the beginning of 1985 because crops ripened and food aid distribution became more efficient. In 1994-96, there was no major famine in the home villages of 
most Meketel settlers, nor throughout the country. "Had they not migrated to Metekel, many of the settlers would have avoided the two famines" (Gebre, 2001).

From the backdrop of the foregoing, migration may be relevant for improved living conditions in Ethiopia if migrants are educated and able to gain access into nonagricultural livelihood sources. However with low levels of education, poor economic opportunities, high levels of unemployment in the urban centers and recurring conflicts, the resort to migration to supposedly better environments, as an individual and household survival strategy and official policy response to periodic drought and famine, may not improve living conditions, it may worsen the situation. The economic, psychological and social stability that may help to translate migration into better living conditions seem to be generally lacking in the country in the period under consideration. With a national literacy rate of 29 percent in 1999-2000 (FDRE 2002:13), policy efforts at poverty alleviation may be effective if they emphasize the promotion of higher education and non-farming livelihood opportunities.

One significant outcome from the descriptive analysis is the low level of participation in agriculture. This outcome obviously does not reflect the efficiency of the agricultural sector, as in developed societies where lower participation reflects better factor utilization. Rather, this may be an indicator of the dwindling levels of participation in the sector following drought, famine, war, and resettlements. Lindstrom and Berhanu (1999) show that the sequence of land and business nationalization, rural resettlement programs, political crackdowns and wars in the 1970s through the 1990s was highly disruptive of economic activity. Accordingly, agricultural production among other economic activities stagnated and real per-capita income fell (Hansson, 1995). This helps to explain the low levels of living conditions associated with agriculture as an income source in this analysis. Agriculture is the primary source of sustenance for people living in rural areas and it is generally the first victim of environmental stress. Research in developing countries confirms that the poor primarily live in rural areas and are predominantly dependent on agriculture. In Ethiopia, rural areas are identified as the worst hit by drought and famine. With no fundamental technological restructuring of agriculture and little or no potential returns to education in the sector, more educated people are likely to continue to migrate to urban areas, thereby depriving rural areas the much needed human capital to boost her transformation and development.

An interesting relationship is identified between household structure and living conditions. As household size increases living conditions improve, and this is significant for the largest households of over ten persons. This advantage may not be unconnected with the role of large families in pooling resources to provide household sustenance, particularly in an uncertain environment. While this outcome is contrary to the modernization paradigm that small-sized family norms should improve living standards, it is supported by other studies in sub-Saharan Africa, Southeast Asia and 
Latin America, in which nuclear households are worse-off than extended households in terms of household amenities and possessions (Gage et al 1997; Cronk, 1991; Otite, 1991). Locoh (1994) have identified the protective role of large families under pervasive uncertainties associated with fluctuations in economic and political conditions, as in Ethiopia.

One surprising outcome is the identified advantage of female-headed households over male-headed households. While this outcome is viewed with caution, other studies in Ethiopia have offered some plausible explanations. One of such explanation is the dominance of men in agriculture, particularly pastoralism, which is a highly vulnerable livelihood system in the country. Constant severe droughts, conflict over land and war cause large-scale livestock mortality, and makes moving to fresh grazing lands almost impossible. This results in thousands of displaced people moving to towns and camps in search of food and employment. In contrast, women are mostly associated with off-farm livelihood activities like handcrafts, sewing, selling of food and petty trading which are more detached from environmental hazards (Massow, 1999). In addition, relief work and the efforts to deliver aid to famine affected areas also may have reduced relocation of women (Berhanu and White, 2000). This becomes even more plausible against the background that most programs on poverty alleviation target women than men. Under these circumstances, female-headed households may have benefited from the advantages of stationary populations and programs that assist their livelihood sustenance. The extent to which the outcome in this analysis is valid may represent the perspective that people are poor and become poor not because they are male or female, but because they are subjected to socioeconomic and political processes that deprive them of access to material conditions of existence (Gimenez, 1999). This underscores the point that programs that target only female poverty may be missing the second half of the fundamentally vulnerable group: poor men.

A methodological contribution of this study is the empirical consistency of the poverty estimates with other studies in the country. Through the use of the household asset-measure of poverty, the regional variations in living conditions identified, mirrors the findings of other studies that used different poverty measures. Sharp et al (2002) used conventional income measures of poverty, and identified Oromiya (as in this study), the most prosperous of all Ethiopian regions. This is attributed to the region remaining the least densely populated in the country with opportunities for more fruitful agricultural expansion and development. In the case of Tigray, (another region of significant better living conditions in this study), census reports confirm improvements in access to social services in Tigray compared to other regions, particularly in education and health indicators (Central Statistical Authority, 1998; 1999). This is linked to the level of political patronage and investment in the region since the coming to power in 1991 of the current government led by the Tigray Peoples Liberation Front 
(Yilma, 2005). In contrast, the concentration of poverty over three regions, particularly Amhara, is congruent with the findings of other studies in the area. The creation of new federated regions based on ethnic nationalities in the early 1990s resulted not only in massive return migration of northern ethnic groups resettled in the south and southwest, but also in widespread human right abuses, including the loss of many lives in which Amhara ethnic settlers in the south were the primary victims (Ezra, 2001). Sharp et al (2002) confirm Ahmara as the region most vulnerable to poverty, and classified 76 percent of households in the region as destitute, significantly food insecure, and less able to meet their basic needs. For the non-destitute households, less than half (43 percent) live in visibly inadequate housing.

Finally, the low levels of living conditions in Addis Ababa raised the genuine concern about the validity of the estimates, but statistical operations (tests of multicollinearity and fixed-effects models to control regional unobservables) specifically to verify the status of the metropolis relative to other regions did not significantly alter this status for the national capital. Apart from a high-level of urban unemployment, decline in real income among employed persons, and the shortage of urban housing, the Red Terror and insecurity due to political problems were more severe in Addis Ababa than in any other city (Berhanu and White, 2000). Recent studies that found below replacement fertility in Addis Ababa primarily attribute the outcome to poverty and high cost of living in the city. This outcome continues to reiterate the increasing concern about the urbanization of poverty in developing countries particularly in sub-Saharan Africa (UN-HABITAT, 2003). In sum, the regional imbalance identified in this analysis, underscores the magnitude of policy efforts needed to promote even development and address issues related to living conditions' inequity in Ethiopia.

\section{Acknowledgements}

The author gratefully acknowledges the assistance of Prof. David P. Lindstrom who provided the data from the Ethiopian Project which made this analysis possible. I also acknowledge the assistance of Dr. Zewdu Woubalem, Dr. Nyovanni Madise and Professor Daniel J. Smith. Thanks to Olumide Taiwo and Roland Pongou for helpful comments and the management of African Population and Health Research Center, Nairobi Kenya, for facilitating my internship in the center during which time this paper was completed. Finally I want to express my appreciation to the anonymous reviewers for their painstaking commitment and great suggestions. 


\section{References}

Adepoju, A. (1977). Migration and Development in Tropical Africa: Some Research, Priorities. African Affairs, 76(33): 210-225.

. (1983). Selected Studies on Dynamics, Patterns and Consequences of Migration: Medium-Sized Towns in Nigeria. Paris, UNESCO, Vol. IV. Pp7-8.

. (1995). Emigration Dynamics in sub-Saharan Africa. International Migration. Special Issue: Emigration Dynamics in Developing Countries, Vol. 33 , nos. 3/4.

Andersson, J.A. (2001). Mobile Workers, Urban Employment and 'Rural' Identities: Rural-Urban Networks of Buhera Migrants, Zimbabwe. In: M. Dedruijn, R. Van Dijk and Dick Foeken (Eds.), Mobile Africa: Changing Patterns of Movement in Africa and Beyond. Lieden, the Netherlands: Brill.

APHRC. (2002). Population and health dynamics in Nairobi Informal Settlements. Nairobi, Kenya: African Population and Health Research Center (APHRC).

Arhinful, D.K. (2001). "We Think of Them": How Ghanaian Migrants in Amsterdam Assist Relatives at Home. Leiden: African Studies Center, Research Report 62.

Bariagaber, A. (1995). Linking Political Violence and Refugee Situations in the Horn of Africa: An Empirical Approach. International Migration, 33(2): 209-234.

Berhanu, B. and M.J.White. (2000). War, Famine and Female Migration in Ethiopia, 1960-1989. Economic Development and Cultural Change, 49 (1): 91-113.

Brockerhoff, M and Brenan, E. (1998). The poverty of cities in developing countries. Population and Development Review, 24 (1):75-114.

Casacchia, O., M. Crisci and C. Reynaud, (2001). Chapter 3: Internal Migration in Ethiopia. In: Migration and Urbanization in Ethiopia, with Special Reference to Addis Ababa. www.irpps.cnr.it/etiopia/sito/progetto3.htm

Central Statistical Authority (1992).The analysis of local moves and internal migration, Vol. II. Addis Ababa, Ethiopia: Central Statistical Authority. . (1998). The 1994 Population and Housing Census of Ethiopian: Result at Country Level, Vol. 1 Statistical Report, June 1998. Addis Ababa, Ethiopia: Central Statistical Authority. 
(1999). The 1994 Population and Housing Census of Ethiopian: Result at Country Level, Vol.11 Analytical Report, June 1999. Addis Ababa, Ethiopia: Central Statistical Authority.

Clapham, C. (1991). The Structure of Regional Conflict in Northern Ethiopia. Disasters 15(3): 244-253.

Cohen J.M. and N.H. Isaksson. (1987). Villagization in the Arsi region of Ethiopia. Uppsala: Swedish University of Agricultural Sciences.

Cronk, L. (1991). Wealth, Status and Reproductive Success among the Mukogodo of Kenya. American Anthropologist 93:345-360.

Dejene, A. (1990). Environment, Famine, and politics in Ethiopia: A view from the Village. Boulder and London: Lynne Rienner Publishers.

Dijk, H.V. and Dick Foekan and Kiky van Til. (2001). Population Mobility in Africa: An Overview. In M. De Bruijn, Rilk Van Dijk and Dick Foekan (Eds.), Mobile Africa: Changing patterns of Movement in Africa and Beyond. Leiden: Brill.

Ezra, M. (2001). Ecological Degradation, Rural Poverty, and Migration in Ethiopia: A Contextual Analysis. Policy Reasearch Division, Population Council Working Paper, No. 149.

FDRE. (2002). Household Income, Consumption and Expenditure (HICE) Surveys, 1999/2000. Addis Ababa: Federal Democratic Republic of Ethiopia (FDRE).

Filmer D. and Pritchett, L. (1998). Estimating wealth effects without income or expenditure data-or tears: Educational enrolment in India. World Bank policy Research Working Paper No.1994. Washington DC: The World Bank.

. (1999). The effects of Household Wealth on Educational Attainment: Evidence From 35 Countries. Population and Development Review 25(1): 85-120.

Fischer, P. A., Reiner Martin, and Thomas Straubhaar, (1997). Should I Stay or Should I Go? In: International Migration, Immobility and Development: Multidisciplinary Perspectives. Oxford and New York: Berg.

Gage, J.A., Sommerfelt, E., Paini, A.L. (1997). Household Structure and Childhood Immunization in Niger and Nigeria. Demography 34(2): 295-309.

Gebre, Y.D. (2001). Population Displacement and Food Insecurity in Ethiopia: Resettlement, Settlers and Hosts. University of Florida: PhD Dissertation.

Gimenez, M.E. (1999). The Feminization of Poverty: Myth or Reality. Critical Sociology 25, 2/3: 336-350. 
Golini, A., M. Said, O. Casacchia, C. Reynaud, S. Basso, L. Cassata, and M. Crisci (2001) Migration and Urbanization in Ethiopia, with special reference to Addis Ababa. La Sapienza, Roma: Department of Demographic Sciences, University of Roma, and Addis Ababa: Central Statistical Authority.

Gurmu, E., Sidney Goldstein and Alice Goldstein, (2000). Migration, Gender and Health Survey in Five Regions of Ethiopia: 1998. (A United Nation Training and Research Project on the Interrelations of Migration and Economic Change, Women's Status, Reproduction and Health). Addis Ababa: Addis Ababa University and Providence: Brown University.

Gwatkin, D.R., S. Rustein, K. Johnson, R.P. Pande, and A.Wagstaff. (2000). Socioeconomic Differences in Health, Nutrition, and Population in Kenya. Washington, DC: HNP/Poverty Thematic Group, The World Bank.

Hansson, G. (1995). The Economy of Ethiopian Economy 1974-1994: Ethiopia Tikdem and After. London: Routledge.

Harrison, P. (1982). Inside the third world. Harmondsworth, UK: Penguin.

Hogan, D.P. and Biratu, B. (2004) Social Identity and Community Effects on Contraceptive Use and Intentions in Southern Ethiopia. Studies in Family Planning, 35 (2): 79 - 90.

Kibreab, G. (1987). Refugees and developments: The case of Eritrea. Trenton, N.J.: The Red Sea Press.

(1996). Eritrea and Ethiopian Refugees in Khartoum: What the Eyes Refuses to See. Africa Studies Review, 39(3):131-178.

Kidane, A. (1989). Demographic Consequences of the 1984-1985 Ethiopian Famine. Demography, 26(3): 515-522.

Kim, J. and Mueller, C.W. (1978). Introduction to Factor Analysis: What It Is and How To Do It. California: Sage Publications Ltd.

Kiros, G-E. and M.J. White. (2004). Migration, community context and child immunization in Ethiopia. Social Science and Medicine, 59: 2603-2616.

Kloos, Helmut. (1990). Health aspects of resettlement in Ethiopia. Social Science \& Medicine, 30(6): 643-656.

(1992). Health Impacts of War in Ethiopia. Disasters, 16(4): 347-354. Kloos, H. and B. Lindtjorn, (1994). Malnutrition and Mortality during Recent 
Famines in Ethiopia: Implications for Food Aid and Rehabilitation. Disasters, 18(23): 130-139.

Korboe, D. (1992). Family-houses in Ghanaian cities: to be or not to be? Urban Studies, 29: $1159 \pm 1172$.

Lindstrom, D.P. and Berhanu, B. (1999). The Impact of War, Famine, and Economic Decline on Marital Fertility in Ethiopia. Demography, 36(2): 247-261.

Lipton, M. (1976). Why poor people stay poor: Urban bias in world development. Cambridge, MA: Harvard University Press.

Lloyd, C.B. (2005) Growing Up Global: The Changing Transitions To Adulthood In Developing Countries. Washington, DC: The National Academies Press.

Lockwood, V. S. (1990). Development and Return Migration to Rural Polynesia.International Migration Review, 24(2): 347-371.

Locoh, T. (1994). Will the Decline in Fertility in Sub-Saharan Africa Last? A Time of Uncertainty. In: T. Locoh and V. Hertrich (eds.) The Onset of Fertility Transition in Sub-Saharan Africa, Liege: IUSSP.

Makinwa, P.K. (1981). Internal Migration and Development in Nigeria: Lessons From Bendel State. Ibadan: Heineman Educational Books (Nig) Ltd.

Mariam, M.W. (1985). The social consequences of famine. In Fasil Gebre-Kiro (ed) Changing Rural Poverty. Trenton: Africa World Press.

Massow, von F. (1999). Oxfam Policy Department: Health and Education in Ethiopia, Summary Reports. London: Oxfam Working Papers.

Mclanahan, S. and Booth, K. (1989). Mother-Only Families: Problems, Prospects and Politics. Journal of Marriage and the Family, 51(3): 557-580.

Megbolugbe, I.F. and Linneman, P.D. (1993). Home-ownership. Urban Studies, 30: 659-682.

Montgomery, M., M. Gragnolati, K. Burke, and E. Paredes (2000). Measuring Living Standards with Proxy Variables. Demography, 37(2): 155-174.

Montgomery, M. and Hewett, P. (2005). Poverty and Children's Schooling in Urban and Rural Senegal. Policy Research Division Working Paper no. 196. New York: Population Council.

Nigeria Institute of Social and Economic Research (NISER). (1997). Nigeria Migration And Urbanization Survey 1993. Ibadan: NISER. 
. 2003. Understanding Poverty in Nigeria. Ibadan: NISER.

Otite, O. (1991). Marriage and Family Systems in Nigeria. International Journal of Sociology of the Family, 21: 15-54.

Pankhurst, A. (1992). Resettlement and Famine in Ethiopia: the villagers; experience. Manchester: Manchester University Press.

Porter, A. (1986). Resettlement in Ethiopia. Lancet, 1, 217.

Rafiq M. and Hailemariam A. (1987). Some structural aspects of urbanization in Ethiopia. Genus. 43(3-4):183-204.

Sharp, K., S. Devereux, and Y. Amare. (2002) Destitution in Ethiopia's Northeastern Highlands (Amhara National Regional State). Sussex: University of Sussex for Save the Children United Kingdom.

Stark, O. and Bloom D.E. (1985). The new economics of labor migration. American Economic Review, 75: 845-867.

UN-HABITAT. (2003). The Challenge of Slums: Global Report on Human Settlements. London and Sterling: Earthscan.

Wachter, S.M. and Megbolugbe, I.F. (1992). Racial and ethnic disparities in Homeownership. Housing Policy Debate, 3: 333 -370.

Wagstaff, A., P. Paci, and E. van Doorslaer. (1991). On the measurement of inequalities in health. Social Science and Medicine, 33(5): 545-557.

Webb, P. and J. von Braun. (1994). Famine and Food security in Ethiopia: Lessons for Africa. Chickesther, United Kingdom: Wiley.

Willis, K.G. and Tipple, A.G. (1991) Economics of multihabitation: housing conditions, Household occupancy and household structure under rent control, inflation, and non-marketability of ownership rights. World Development, 19(1705-1720).

Yilma, T. (2005). The Eriterean and Tigrean Ascaris War in Defense of a Colonial Boundary: Badme. Http://www.ethiopic.com/ethiopia/tilahun6.htm.

Zulu, E. M., F. N. Dodoo, and A.C. Ezeh. (2002). Sexual risk-taking in the slums of Nairobi, Kenya, 1993-1998. Population Studies 56(3): 311-323. 
Mberu: Internal migration and household living conditions in Ethiopia 